\title{
METHODS USED TO MANAGE DEFECTS RELATED TO VEGETABLE TANNED LEATHER
}

\section{Jennifer Tabi SEFAAH*, Eric Apau ASANTE, Kwadwo Fosu DUAKO}

Department of Educational Innovations in Science and Technology, College of Art and Built Environment, KNUST, Kumasi, Ghana

Received: 01.03.2019

Accepted: 06.05.2019

https://doi.org/10.24264/Ifj.19.2.4

\section{METHODS USED TO MANAGE DEFECTS RELATED TO VEGETABLE TANNED LEATHER}

ABSTRACT. Leather surface quality is vital when it comes to leather artifact production. Users of the locally produced vegetable tanned leather adopt various methods to manage and improve on the poor surface quality of leather produced in Ghana. Students from the various secondary schools and local craftsmen who often depend on the vegetable tanned leather for it inherits unique properties such as flexibility, resilience, breathability, perspiration, durability and mechanical strength adopt various methods to improve on the surface quality and also meet the market standard. The necessity for quality leather surface in leather artefact production has called for the need for corrective measures to manage defects associated with vegetable tanned leathers produced in Ghana. Stains, cuts, holes, grain loosing, creases, wrinkles, scratch marks, bacterial and viral infections are common defects which affect the quality of vegetable tanned leathers produced in Ghana. Defect managing methods such as dyeing, painting, screen printing, stamping, appliqué, and scorching adopted by leather users to manage surface defects were examined for their viability in this current study.

KEYWORDS: vegetable tanned leather, defects, managing methods, viability

\section{METODE PENTRU GESTIONAREA DEFECTELOR PIEILOR TĂBĂCITE VEGETAL}

REZUMAT. Calitatea suprafeței pielii este vitală atunci când vine vorba despre producția de artefacte din piele. Utilizatorii pieilor tăbăcite vegetal produse la nivel local adoptă diverse metode de gestionare şi îmbunătăţire a calității slabe a suprafeței pieilor produse în Ghana. Elevii din diferite licee şi meșteșugarii locali care depind adesea de pielea tăbăcită vegetal care are proprietăți unice, cum ar fi flexibilitatea, rezistența, respirabilitatea, permeabilitatea la vapori de apă, durabilitatea şi rezistența mecanică, adoptă diferite metode de îmbunătăţire a calității suprafeței, pentru a se conforma standardelor pieții. Necesitatea pielii cu suprafață de calitate înaltă în producția de artefacte din piele a impus luarea unor măsuri corective pentru a gestiona defectele pieilor tăbăcite vegetal produse în Ghana. Petele, tăieturile, găurile, curgerea feței, cutele, încreţiturile, zgârieturile, infecțiile bacteriene şi virale sunt defecte comune care afectează calitatea pieilor tăbăcite vegetal produse în Ghana. În acest studiu s-a examinat viabilitatea metodelor de gestionare a defectelor, cum ar fi vopsirea, pictarea, serigrafierea, ştanţarea, aplicarea cusăturilor şi pirogravura, adoptate de utilizatorii de piele pentru a gestiona defectele de suprafață. CUVINTE CHEIE: piele tăbăcită vegetal, defecte, metode de gestionare, viabilitate

\section{MÉTHODES POUR GÉRER LES DÉFAUTS DU CUIR TANNÉ VÉGÉTAL}

RÉSUMÉ. La qualité de la surface du cuir est essentielle pour la production d'artéfacts en cuir. Les utilisateurs de cuir tanné végétal produit localement adoptent diverses méthodes pour gérer et améliorer la qualité de surface médiocre du cuir produit au Ghana. Les étudiants des différentes écoles secondaires et les artisans locaux qui dépendent souvent du cuir tanné végétal aux propriétés uniques telles que la souplesse, la résilience, la respirabilité, la perméabilité à la vapeur d'eau, la durabilité et la résistance mécanique adoptent diverses méthodes pour améliorer la qualité de la surface et s'adaptent également aux normes du marché. La nécessité d'une surface en cuir de qualité dans la production d'artéfacts en cuir a nécessité de mesures correctives pour gérer les défauts associés aux cuirs à tannage végétal produits au Ghana. Les taches, les coupures, les trous, la fleur creuse, les plis, les rides, les égratignures, les infections bactériennes et virales sont des défauts communs affectant la qualité des cuirs à tannage végétal produits au Ghana. Les méthodes de gestion des défauts telles que la teinture, la peinture, la sérigraphie, l'estampage, les appliqués et la pyrogravure adoptées par les utilisateurs de cuir pour gérer les défauts de surface ont été examinées dans la présente étude pour déterminer leur viabilité.

MOTS-CLÉS : cuir tanné végétal, défauts, méthodes de gestion, viabilité

\footnotetext{
* Correspondence to: Jennifer Tabi SEFAAH, Department of Educational Innovations in Science and Technology, College of Art and Built Environment, KNUST, Kumasi, Ghana, sefaah.tabi@gmail.com
} 


\section{INTRODUCTION}

All skins and hides have natural defects which attest to the genuineness of leather though not desirable on the finished leather product [1]. Quality is a crucial factor in leather product consumption. Defect on leather surfaces affect the quality of the leather product and furthermore, restrict the development of the leather industry [2]. These defects occur during life and death of the animal $[3,4]$. Defects that occur when the animal is still alive include, cuts resulting from barbed wire, in-fighting among male members, thorn scratches and cuts; brand marks made for ownership purposes using hot iron; holes and spots from infestations and infections caused by ticks, horn flies, mange and bot-flies; abscesses resulting from wrong vaccination techniques and wrinkles resulting from natural growth marks or excess weight related problems [4]. Defects which occur at the death of the animal may result from improper handling of various techniques during skin transportation and production. According to [4], defects which occur during skin production are much less common as they are controlled by tanneries which have quality leather production as their main business. Leathers go through treatment operations to control such defects and also improve on the final appearance of the leather $[5,6]$.

In Ghana, leather is obtained from the southern and Northern part of the country. Leather from these areas are often of show defects with little or no surface treatment [3]. The leather shows defect such as abscess, blind warble wholes, brand mark, dung damage, eczema, scar mark, grain break, blisters, holes, flay cuts and grain peeling $[7,8]$. According to [3], observations made in the various leather shops in Kumasi, Accra and Takoradi show that the vegetable tanned leather is not a material of choice due to various surface defects associated with the leather. Significance of the leather is very limited for products such as footwear, sofas, bags, jackets, gloves, car seats, car seat backs and spare tyre covers which are commonly used by Ghanaians. Imported leather and leatherette are bought at high cost although most of these materials lack the imperative properties of vegetable tanned leather such as resilience breathability, perspiration, durability, tooling and ability to model and form to shape as emphasized by [9].

Since leather is mostly used for visually appealing products like upholstery, footwear, bags, jackets and car seats, excellent optical properties of materials is a great requirement [10]. Users of the vegetable tanned leather in Ghana adopt several methods to manage and improve on the quality of leather and its products to meet market standards. Students of leather in various institutions in Ghana who are required by curriculum [11] to use vegetable tanned leather for their course work adopt various managing methods to manage defects and improve on the quality of leather products [12]. Leather craftsmen who produce leather products for market supply also adopt various methods to manage defects and improve on the quality of the leather products produce on the Ghanaian market. The research examines the methods implemented by users of locally produced vegetable tanned leather and the viability of the methods by identifying their strengths and weakness.

\section{MATERIALS AND METHODS}

Users of the locally produced vegetable tanned leather were students from the second and tertiary education institutions in the Kumasi metropolis of Ghana and leather craftsmen from Bolgatanga in the Northern part of Ghana. The research adopted the purposive and the convenience sampling technique to sample a population of 20 students who make use of locally produced vegetable tanned leather from the department of Integrated Rural Art and Industry in the Kwame Nkrumah University of Science and Technology (KNUST). 31 visual Arts students from second cycle institution in the Kumasi metropolis of Ghana and 5 local craftsmen from Bolgatanga Craft Village. Face to face interview were conducted with the respondents on methods they adopt in managing locally produced vegetable tanned leather surface defects. Observation of products are made to 
further analyze the methods used in situations where samples of works were available.

\section{RESULTS}

The local leather craftsmen adopt two methods to manage locally produced vegetable tanned leather surface defects. Defects may be ignored or occasionally leather be discarded when these two methods are unable to manage defects. This affect the aesthetic appearance of the leather products produce on the market by the local leather craftsmen. The following methods are adopted by leather craftsmen to manage defect with vegetable tanned leather.

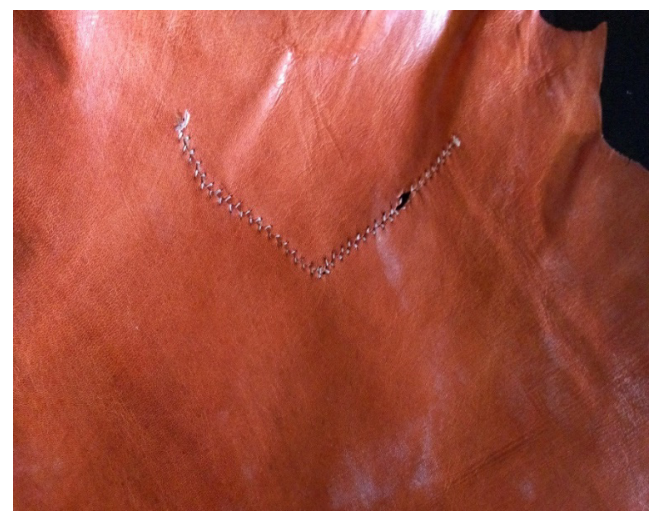

Figure 1. Patched leather with strip of leather

Source: Field photograph, February-May, 2017

\section{Dyeing}

The local leather craftsmen manage dark brown spots which may result from stains and parasitic infections by changing the original khaki colour of the leather to red, coffee brown or black. Colour is much dependent on the intensity and nature of the defect. Leathers with less intense defects are often dyed red or coffee brown whereas the very intense leathers are dyed black.

When dyeing red colour, the local craftsmen use the stalk of a sorghum plant. The sorghum stalk is boiled in water to extract

\section{Tack Patching}

Tack patching is a leather defect management method used by some local leather craftsmen to repair defects like open cuts and larger holes on surfaces of vegetable tanned leathers. In tack patching, a strip of leather or plastic yarn is used to join an open cut or hole in a leather by means of hand stitching. Though tack patching ensures closure of open cuts and holes, stitch lines which are formed on the leather surface after patching remain as another form of defect as shown in Figures 1 and 2. Leather users trim Patched areas during leather artefact production because the presence of the stitch lines interrupt with the leather's surface grain structure and reduce the aesthetic appearance of the leather and artefacts produced from the leather.

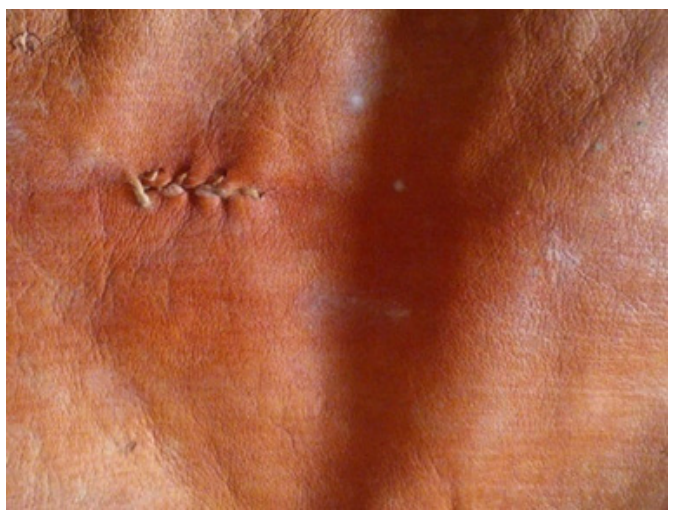

Figure 2. Patched leather with plastic yarn Source: Field photograph, February-May, 2017

colour. The leather is also soaked in water between three to four days and later pounded to soften and open the pours of the leather fiber to enable penetration of the dye into the fibres of the leather. The leather is soaked in the boiled sorghum stalk solution for five to seven days depending on the intensity of red colour needed. The leather is removed from the solution and stretched under a shed to dry.

For black and coffee brown colour, the dye is obtained by rusting metals with iron content in a lime or lemon solution. The lime or lemon solution facilitates the rusting of the iron metals to obtain a dark brown or black chemical 
for changing the khaki or red leather to coffee brown or black colour. The leather to be dyed is first soaked in water and transferred into the rusted iron solution after two to three days. The length of the time the leather is soaked in the rusted solution is dependent on the shade of coffee brown colour required. For black colour, the leather is soaked in the solution for a very

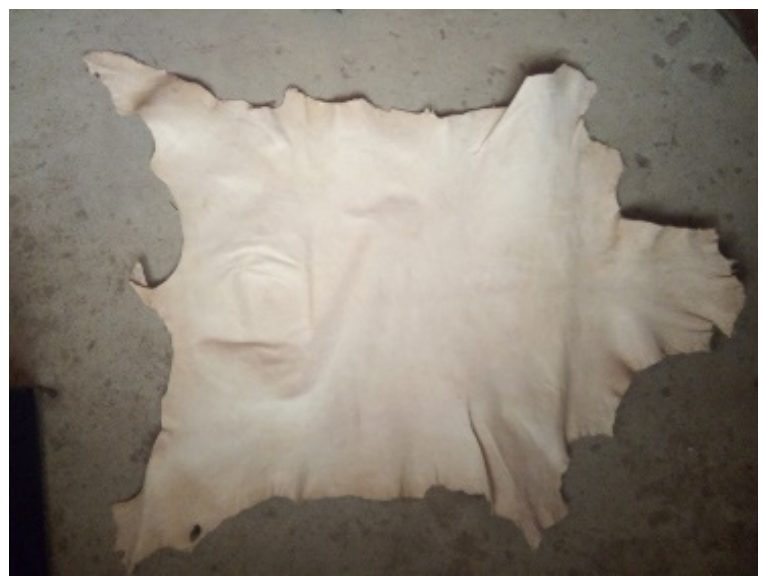

Figure 3. Cream dyed leather Source: Field photograph, February-May, 2017

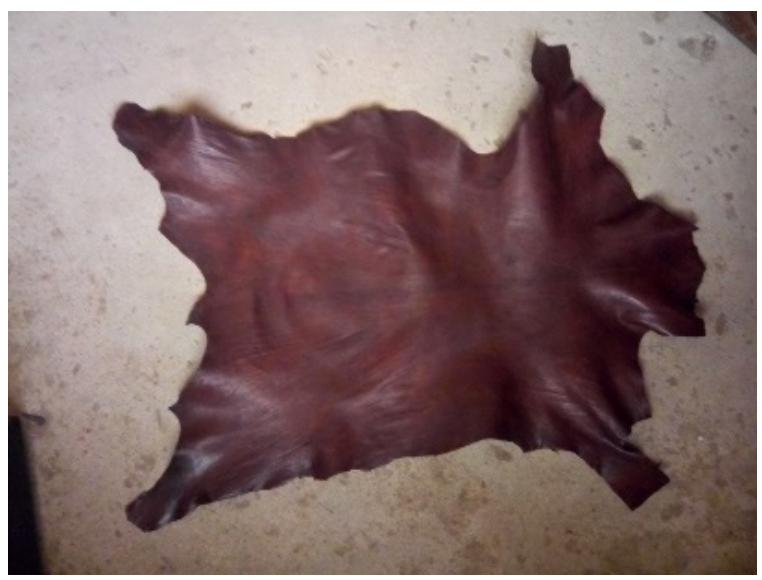

Figure 5. Coffee brown leather Source: Field photograph, February-May, 2017

Students of leather adopt more methods than the local leather craftsmen who produce on the market. Students adopt the following methods to manage various defects on vegetable tanned leather surfaces to enable them produce leather products with outstanding surface appearance.

Dyeing is done in two ways by students. Dyeing by immersion which involves submerging long time that is for about three weeks to a month. When the right colour is obtained, the leather is removed from the colorant and dried under shade. Black colour dyeing according to the craftsmen is best at hiding different kinds of stain defects and parasitic infections than red colour dyeing. Black colour dyeing also reduces the intensity of grain peeling and scratch marks defects.

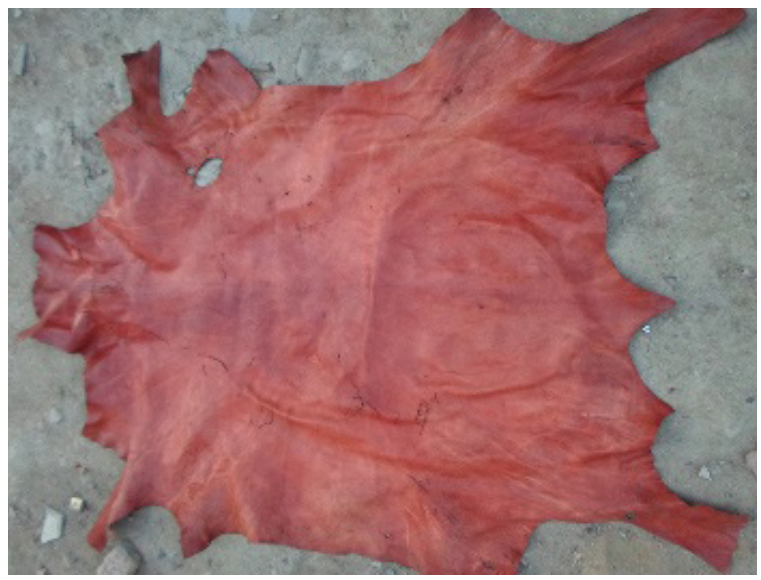

Figure 4. Red leather Source: Field photograph, February-May, 2017

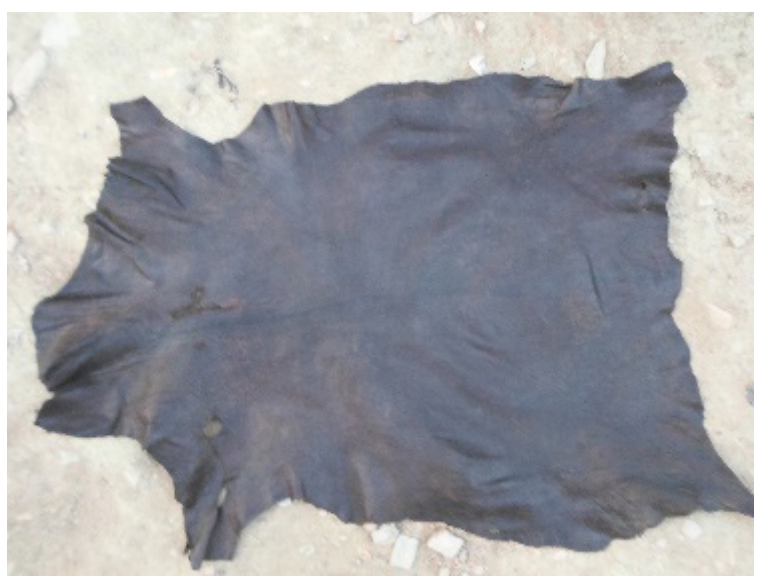

Figure 6. Black leather Source: Field photograph, February-May, 2017

the whole leather into a dye solution called dye bath. Dye bath is prepared by mixing vat dye of their preferred colour with warm water, sodium hydroxide (caustic soda) and sodium hydrosulphite (hydros) in the ratio, 3:1:3. The caustic soda and hydros in dye bath ensure colour fastness and brightness. With this method, the brightness of the colour after dyeing is dependent on the concentration of the dye in 
the solution. In the process of dyeing, Leather is wet with water to open up fibers and immersed into a dye bath. The leather is allowed to stay in the bath for about 10 to 15 munites and spread out under a shade to oxidize or change colour. The leather is washed in clean water to remove excess dye after colour change and finally dried.

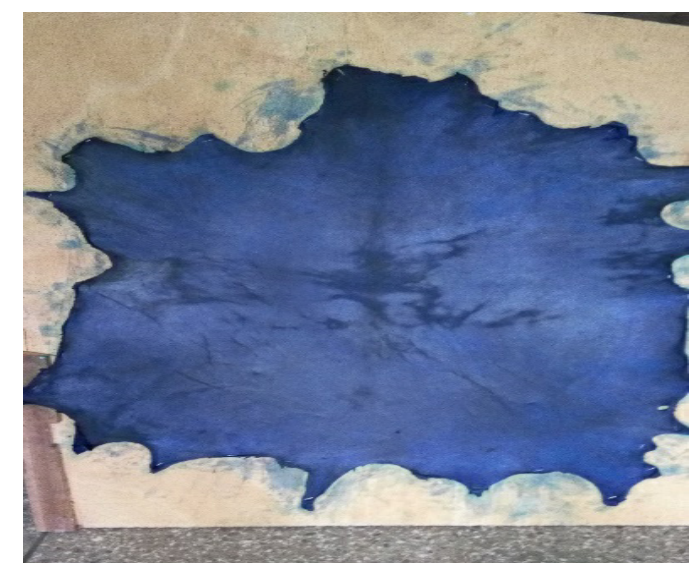

Figure 7. Leather dyed by immersion

Source: Department of Integrated Rural Art and Industry Leather Studio, KNUST

Marbling is the second technique students adopt in dyeing their leather to manage defects. In marbling, leather is soaked in water and beaten in mortar with pestle to soften the leather and open up its fibers to ensure effective penetration of dye into the fibers. The leather is spread out on a clean large table and gently gathered by pulling it with the fingers bit by bit towards the center. With the help of a table-spoon, prepared dye is fetched and spread evenly all over the leather. The leather is left to stand under a shade for about 10 to 15 minutes to oxidize or change colour. The leather is washed in clean water and allowed to dry under a shade.

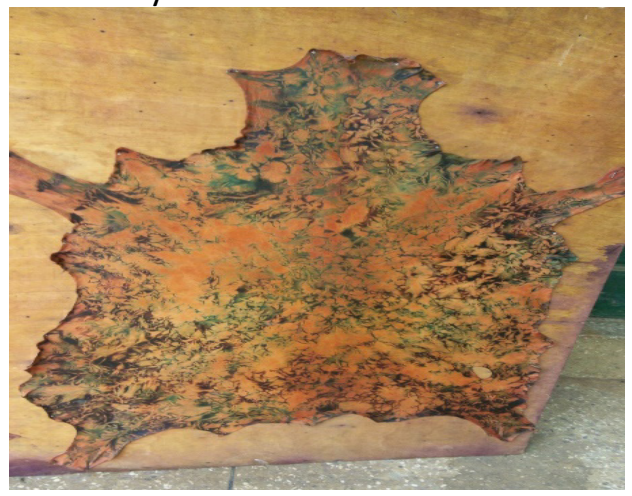

Figure 8. Marbled leathers

Source: Kumasi Technical Institute Visual Arts Department
According to leather users, the marbling technique is a more effective method in managing leather surface defects such as stains, grain peelings, parasitic infections, wrinkle marks, hair remains and shallow cuts than dyeing by immersion. This is because the different shapes, lines and shades of colour produced on the leather surface after dyeing (Figure 8) mingles and subdue defects making them less visible.

Despite the effectiveness of dyeing as a method of managing locally produced vegetable tanned leather surface defects like stains, grain peelings and parasitic infections, the following weaknesses were shared by students who adopt these methods.

According to leather users, it takes at least a whole day to dye and get leather dried for use on a normal sunny day. In a situation where the atmosphere is humid and leather is dense, leather can take more than a day to dry depending on its thickness. In view of this, it becomes a great challenge for the student to adopt this method when they do not have the luxury of time.

\section{Painting}

In painting, colour is applied on leather surfaces with brushes to manage surface defects such as stains, scratch marks, parasitic infections and sometimes minor cuts. Painting, allow students to express various ideas on surfaces of vegetable tanned leather which do not only manage surface defects, but also contribute to the value of the aesthetic appearance of the leather and products produced from them. Because vegetable tanned leather is highly absorbent, colours which are applied on their surfaces are able to fix well. According to users, though painting is an effective way of managing leather surface defects, there are some challenges students face when adopting this method.

In order to produce good painting a special skill is required. Good painting contributes beauty and quality to work. When painting is poor, the entire work become less attractive. In order to produce leather works with outstanding surface appearance, leather users who lack good painting skills but desire to produce good paintings employ professionals who render the 
services to them at a fee which adds to the cost of production.

Painting becomes time consuming when leather surface is large or when scenes, motifs and images to paint are comprehensive. According to users, it is difficult to rectify mistakes when painting on vegetable tanned leather surfaces. Once the leather receives paint, cleaning the paint when a mistake occurs becomes impossible because of the high moisture absorbency rate of the vegetable tanned leather. Painting is not the right surface defect managing method for locally produced vegetable tanned leather when a single colour or the usual cream, red, coffee brown and black colour is desired by the consumer as shown in Figure 9.

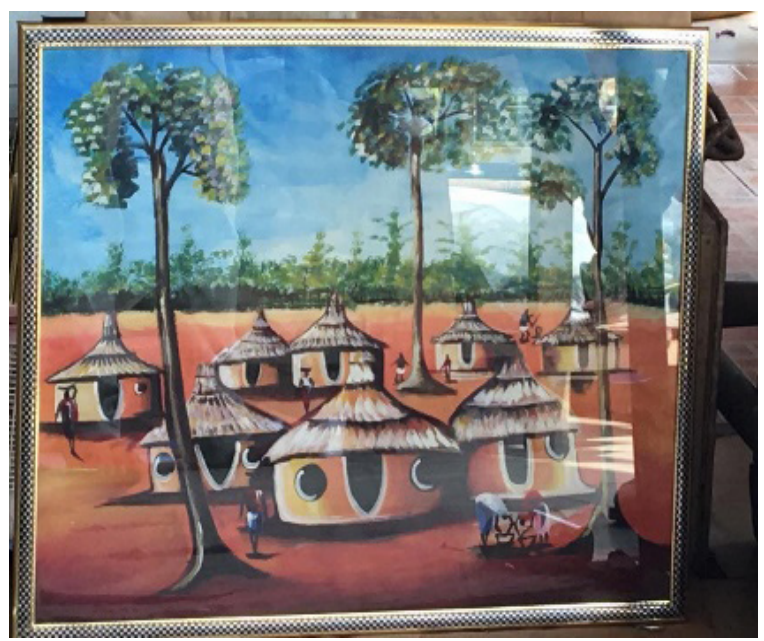

Figure 9. Painted leather

Source: Department of Integrated Rural Art and Industry, KNUST

\section{Screen Printing}

Just like painting, screen printing is the application of colour onto a leather surface but with a different application method. With screen printing, print paste is forced through a mesh with a design to be printed from a mesh but in a reversed form so that when printed the colour can be obtained in the positive side of the leather surface. The negative areas of the design to be printed from mesh onto leather surfaces are blocked by making blocked areas impermeable to colour. Using a squeegee (a flat pallet knife for forcing paint through holes of mesh), colour is forced through the open areas of the mesh whiles it rest on the leather surface to be printed. Screen printing, just like painting, is able to manage stains and subdue defects like minor cuts, parasitic infections and sometimes hair remains. Screen printing unlike painting is less time consuming especially when the same design is required for a mass production. Screen printing becomes much expensive and time consuming when variations are required in mass production. Screen printing unlike painting gives room for less mistakes because prints are defined by the mesh. Challenges associated with screen printing as a leather surface defect managing method is the management of different leathers with defects messily spread on their surfaces with the same design frame. While some defects may be covered by colour spread through the mesh, other defects may also hide under blocked areas of the mesh making them visible after the screen printing. Just like painting, screen printing cannot be the right leather surface defects management method when the usual colour of the locally produced vegetable tanned leather is desired by the consumer. Figure 10 shows screen print made on vegetable tanned leathers to manage leather surface defects.

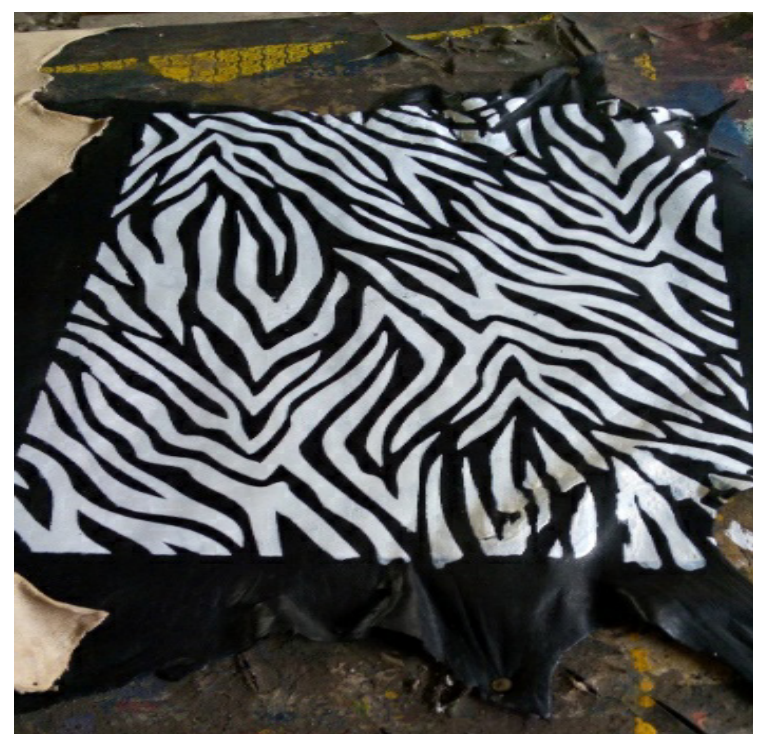

Figure 10. Screen printing on black leather Source: Department of Integrated Rural Art and Industry, KNUST

\section{Scorching}

Scorching is the use of hot metal rod or soldering iron to burn designs on vegetable tanned leather surfaces with the purpose of managing defects. Scorching creates varying shades and tones on vegetable tanned leather surfaces. Scorching 
manage defects like parasitic infections, stains, scratches, hair remains and scars by mingling with the defects and subduing their clarity. Scorching according to users of the leather best manages these defects when scorching design forms texture on the leather surface.

According to leather users, the ability to create interesting scorched designs on the leather is dependent on the one handling the scorching tool. Right control of temperature and the ability to choose the right soldering iron tips is paramount. Lack of these skills contributes additional damage to the leather instead of managing defects on them. Scorching is effective on cream and red leathers than on black and coffee brown leathers. The dark appearance of black and coffee brown leather is unable to bring out shades and tones burned on the leather surfaces.

\section{Stamping}

Stamping is the use of pressing tools in the form of metal rod with motif at one end of the rod to produce a repetitive pattern on leather surfaces. In stamping, leather is placed on a punching board or any hard resilient surface and with a mallet, a stamping tool is striked to print pattern on leather surfaces. According to users, stamping reduces the surface glossiness of leather and leaves the leather surfaces rough and matt. When stamping, as the number of patterns increases or repeated, they fuse together and reduce the visual clarity of the leather surface as well as defects by obscuring the defects.

Defects like creases, wrinkles and minor scratches according to users of this method are best concealed when stamping patterns are small, numerous and closely parked on the surface.

Although according to leather users, stamping is an effective method for reducing the intensity of leather surface defects like creases, wrinkle marks and scratches, the method is labour intensive and time consuming, more especially when the stamping surface area is large. Again, producing patterns with same depth is less assured since the method is manual and for that matter the striking force may differ (Figure 11 shows a leather belt with a varying stamped depth). The users of this method also reported that, there is always the danger of injuring themselves when striking the stamping tools with mallet.

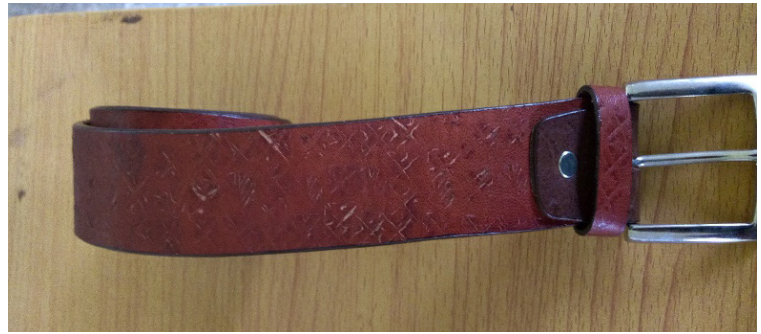

Figure 11. Stamped leather belt with varying depth Source: Department of Integrated Rural Art and Industry, KNUST

\section{Appliqué}

Appliqué is a method employed in controlling leather surface defects by fixing a second leather or a different material over a defected leather's surface area to mask defects and also create design on the leather surface. A leather or a different material with a colour different from the working leather is often fixed to the working leather's surface to mask defects as showed in Figure 12. Leather may be attached to a defected leather surface by either gluing or stitching it manually or with machine. This method is effective because defects are completely masked.

Appliqué becomes an expensive and tedious method to use when the defect spreads on a large surface area of the leather. This is because leather users require a lot of time combined with effort and skill to mask all defects. In addition, when the entire surface area of the leather is defected, this method cannot be adopted because masking the entire surface area of the leather will result in bonded leather instead of an appliqué work. Again the beauty of an appliqué work is much dependent on the leather user's skill to produce an appliqué which conform perfectly to the work.

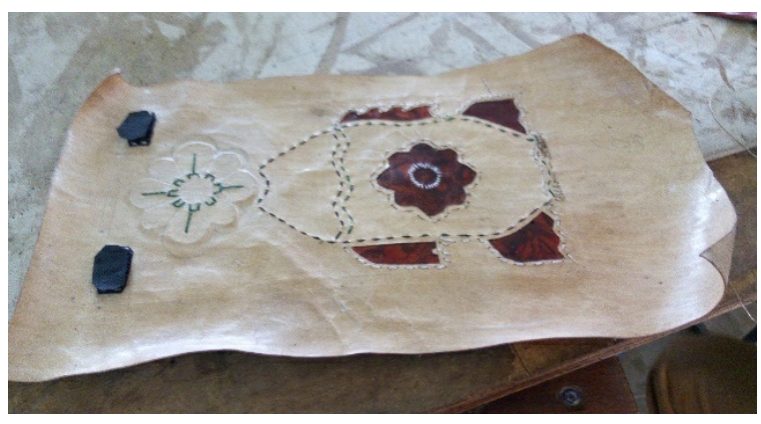

Figure 12. Appliqué leatherwork for masking defects

Source: Prempeh College Leather Studio 


\section{CONCLUSION}

Leather users adopt patching of holes and open cuts, dyeing, painting, screen printing, scorching, stamping and appliqué for managing various leather defects. The research revealed that these methods which are employed by leather users in managing leather defects have their own strengths and weaknesses. In the case of painting, dyeing and screen printing, methods hide stains, minor scratches and grain peeling defects but in situations where the actual colour of the leather is required of a work, these methods become less feasible. Though stamping is an effective method for reducing the intensity of leather surface defects like creases, wrinkle marks and scratches, the method is labour intensive and time consuming, more especially when the stamping surface area is large. Again, producing pattern with same striking force is less assured since the method is manual and for that matter, the striking force may vary. In the case of appliqué, scorching and painting, special expertise is required of the vegetable tanned leather user to be able to effectively employ the methods. Users who lack the skills rely on professionals who render the service to them at a fee which add to their cost of production.

\section{REFERENCES}

1. Carolina Leather Works, About Leather, 2016, carolinaleatherworks.stores.yahoo.net/ allableat.html.

2. Li, J., Han, W., He, B., Research on the inspection and classification of leather surface defects based on neural network and decision tree, 2010 International Conference On Computer Design and Applications, 25-27 June 2010, Qinhuangdao, China, https://doi. org/10.1109/ICCDA.2010.5541405.

3. Asubonteng, K., Improving the Quality of Ghanaian indegineous leatherwork: Alternative strategies, KNUST: PhD dessertation, Department of General Art Studies, 2010.

4. Georgieva, L., Krastev, K., Angelov, N., Identification of surface leather defects, Proceedings of the $4^{\text {th }}$ international conference conference on Computer systems and technologies: e-Learning, CompSysTech '03, June 19-20, 2003, Rousse, Bulgaria, 303-307, https://doi.org/10.1145/973620.973670.
5. BIP (Oldbury) Limited, Leather finishing, September 7, 2016, www.bip.co.uk/marketsleather.htm.

6. Leather Sellers Company, Leather Manufacturing Process, 2016, www. leathersellers.co.uk/content.php?pid=96.

7. Coxon, J.H., Defects in Vegetable Tanned Leather, http://www.coxontool.com/index. php/Leather/Defects.

8. Kahsay, T., Negash, G., Hagos, Y., Hadush, B., Pre-slaughter, slaughter and post-slaughter defects of skins and hides at the Sheba Tannery and Leather Industry, Tigray region, northern Ethiopia, Onderstepoort J Vet Res, 2015, 82, 1, https://doi.org/10.4102/ojvr. v82i1.931.

9. Boahin, J.O.B., Principles and Techniques of Leatherwork for Schools and Colleges. Principles and Techniques of Leatherwork for Schools and Colleges. Kumasi: s.n., 2005, pp. 1-9.

10. Fraunhofer Institute for Industrial Mathematics ITWM, Quality Control of Leather, 2019, https://www.itwm.fraunhofer. de/en/departments/bv/quality-asuranceand-optimization/quality-control-of-leather. html

11. Curriculum Research and Development Division, Teaching Syllabus for Leatherwork (Senior High School 2-4), 2008, www.kosec. xtreemhost.com/syllabus/leather work.pdf.

12. Sefaah, J.T., Asante, E.A., Arthur, N.A.P., Design and construction of a texturing device for locally produced vegetable tanned leather surface, British Journal of Innovation in Science and Technology, 2018, 3, 1, 5-16, https://doi.org/10.22406/bjist-18-3.1-5-16.

(C) 2019 by the author(s). Published by INCDTP-ICPI, Bucharest, RO. This is an open access article distributed under the terms and conditions of the Creative Commons Attribution license (http://creativecommons.org/licenses/ by/4.0/). 